\title{
Feeding behavior and physiological parameters of rearing goats fed diets containing detoxified castor cake
}

\section{Comportamento alimentar e parâmetros fisiológicos de cabritas recriadas consumindo dietas contendo torta de mamona destoxificada}

\author{
Ricardo Alves de Araújo ${ }^{1 *}$; José Neuman Miranda Neiva²; Roberto Cláudio \\ Fernandes Franco Pompeu ${ }^{3}$; Magno José Duarte Cândido ${ }^{4}$; Marcos Cláudio \\ Pinheiro Rogério ${ }^{3}$; Ronaldo Carlos Lucass; Samuel Rocha Maranhão; \\ Renato Gomes Fontinele ${ }^{6}$; Antônio Silvio Egito ${ }^{3}$
}

\begin{abstract}
The objective of this study was to evaluate the influence of replacing soybean meal (SM) with castor bean cake (DCC), detoxified using two alkaline products, on the feeding behavior and physiological parameters of Saanen and Anglo-Nubian goat breeds with an initial body weight of $16.22 \pm 0.67 \mathrm{~kg}$. The treatments consisted of three diets that were isoproteic and isoenergetic: the first with a standard formulation based on corn and SM, the second with DCC detoxified using calcium hydroxide $\left(\mathrm{Ca}(\mathrm{OH})_{2}\right.$ DCC), and the third with DCC detoxified using sodium hydroxide ( $\mathrm{NaOH}$ DCC). A completely randomized design with a $3 \times 2$ (diets and breeds) factorial arrangement and four replicates per combination was used. A dietary effect on the intake of dry matter (DM) and NDFap ( $\mathrm{P}=0.02$ and 0.01$)$ was observed, with lower values for goats fed $\mathrm{NaOH}$ DCC than the other diets. The diets influenced feeding and rumination times $(\mathrm{P}=0.04$ and 0.03$)$. An interaction $(\mathrm{P}=0.04$ and 0.01$)$ between the breeds and the SM-based diet was found for time variables (other activity and idle time). Increased feeding and neutral detergent fiber (NDF) rumination efficiencies were observed for goats fed $\mathrm{SM}$ and $\mathrm{Ca}(\mathrm{OH})_{2}$ DCC $(\mathrm{P}=0.03$ and 0.01$)$. Goats fed the $\mathrm{NaOH}$ DCC diet consumed large amounts of water, while Saanen goats urinated more times than did Anglo-Nubian goats. The diets had an effect on the heart rate and rectal temperature $(\mathrm{P}=0.01$ and 0.02$)$, while the body surface temperature was influenced by the breed. Thus, $\mathrm{Ca}(\mathrm{OH})_{2}$ or $\mathrm{NaOH}$ DCC has a great potential to replace SM in the feeding of dairy goats. When used as diet for goats in the growth phase, $\mathrm{NaOH}$ DCC causes a reduction of DM and NDF intakes. Neither DCC negatively affected the physiological parameters of goats.
\end{abstract}

Key words: Water. Anglo-Nubian. Calcium. Rumination. Sodium. Saanen.

\footnotetext{
1 Discentes de Doutorado em Zootecnia, Programa de Doutorado Integrado em Zootecnia UFC/UFRPE/UFPB, Universidade Federal do Ceará. Departamento de Zootecnia, Fortaleza, CE, Brasil. E-mail: ricardo_zoo@hotmail.com; samuelzootec@ gmail.com

2 Prof. Dr., Universidade Federal do Tocantins, UFT, Araguaína, TO, Brasil. E-mail: araguaia2007@gmail.com

3 Pesquisadores, Empresa Brasileira de Pesquisa Agropecuária, EMBRAPA Caprinos e Ovinos, Sobral, CE, Brasil. E-mail: robertopompeu@embrapa.br; marcos.claudio@embrapa.br; antoniosilvio.egito@embrapa.br

4 Prof. Dr., Universidade Federal do Ceará, UFC, Fortaleza, CE, Brasil. E-mail: magno@ufc.br

5 Pós-Doutorando, UFC, Bolsista Capes/EMBRAPA, Brasil. E-mail: ronaldoclucas@gmail.com

6 Zootecnista, M.e em Zootecnia, Brasil. E-mail: renato.gomes.fontinele@gmail.com

* Author for correspondence
} 


\title{
Resumo
}

\begin{abstract}
Objetivou-se avaliar a influência da substituição do farelo de soja (FS) pela torta de mamona destoxificada (TMD) por dois produtos alcalinos sobre o comportamento alimentar e parâmetros fisiológicos de cabritas das raças Saanen e Anglo-nubiana, com peso corporal inicial de 16,22 $\pm 0,67$ $\mathrm{kg}$. Os tratamentos consistiram de três dietas, uma com formulação padrão à base de milho e FS e as demais foram formuladas com torta de mamona destoxificada por hidróxido de cálcio $\left(\mathrm{TMD} \mathrm{Ca}(\mathrm{OH})_{2}\right)$ e outra por hidróxido de sódio (TMD $\mathrm{NaOH}$ ), as quais foram isoproteicas e isoenergéticas. Utilizouse um delineamento inteiramente casualizado, com arranjo fatorial $3 \times 2$ (dieta e raça) com quatro repetições por combinação. Houve efeito das dietas sobre o consumo de MS e FDNcp ( $\mathrm{P}=0,02$ e 0,01), com menores valores para as cabras alimentadas com TMD NaOH. As dietas influenciaram os tempos de alimentação e ruminação $(\mathrm{P}=0,04$ e 0,03$)$. Houve interação $(\mathrm{P}=0,04$ e 0,01$)$ entre as raças e dieta à base de FS para as variáveis tempo com outras atividade e ócio. Observou-se maiores eficiências de alimentação e ruminação da FDN para as cabras que consumiram FS e TMD Ca(OH $)_{2}(\mathrm{P}=0,03$ e 0,01$)$. As cabras da dieta TMD NaOH consumiram maiores quantidades de água e as Saanen urinaram mais vezes que as Anglo-nubiana. Houve efeito das dietas sobre a frequência cardíaca e temperatura retal ( $\mathrm{P}=$ $0,01$ e 0,02$)$, já a temperatura corporal foi influenciada pelas raças. A torta de mamona destoxificada pelo hidróxido de cálcio e/ou hidróxido de sódio tem grande potencial para substituir o farelo de soja na alimentação de cabras leiteiras. Quando usado na composição de dietas para caprinos em fase de crescimento, a torta de mamona destoxificada pelo hidróxido de sódio leva à redução do CMS, bem como da FDN. Ambas as tortas não alteram negativamente os parâmetros fisiológicos das cabras.
\end{abstract}

Palavras-chave: Água. Anglo-nubiana. Cálcio. Ruminação. Sódio. Saanen.

\section{Introduction}

Because of the increasing demand for food from animal and plant origin, there is a need for prospecting alternative ingredients to formulate ruminant diets, in order to not compete with noble ingredients that are also consumed directly in human diets.

One of the possibilities of feedstuffs alternative to those traditionally used in ruminant diets are byproducts originating from the biodiesel industry, a prominent example of which are those derived from castor (SEVERINO et al., 2012). The limitation for using castor bean cake in animal feed is due to the presence of ricin in castor bean seeds, which is a toxic glycoprotein consisting of two subunits, A (36 kDa) and $\mathrm{B}(29 \mathrm{kDa})$, bound by disulfide bonds (ASLANI et al., 2007). The ingestion of castor seeds may cause intoxication in ruminants (WORBS et al., 2011).

Recent studies have shown the potential of using detoxified castor cake and castor bean meal instead of soybean meal in ruminant diets (POMPEU et al., 2012; FURTADO et al., 2012; GIOMBELLI et al., 2014; NICORY et al., 2015). However, few experiments have been carried out using dairypurpose goats during the growth phase. This is mainly because, on dairy farms, goats that are not under production are viewed as a great source of expenditure, which has somehow not drawn the attention of researchers in performance evaluations during the growth phase. The use of the abovementioned by-products can improve efficiency of the growth phase and positively influence the productive performance of future dairy goats.

We must also consider the interaction between animals of different breeds and their breeding environment. This is especially necessary for confined animals, since the implemented management represents a large part of the obtained results. Scientific research has advanced in the area of animal nutrition, especially regarding the study of animal behavior and physiological processes and how different factors affect them, particularly when there are changes in the supplied diets. 
In this context, residues from the biodiesel industry, especially castor cake, can be used as an alternative food for ruminants in Brazilian semiarid regions, replacing soybean meal, which is a noble food used in human diets, thereby increasing production costs. In an effort to minimize the negative effects brought about by the low supply of soybean meal at certain times of the year, we proposed the use of castor cake detoxified using alkaline solutions as a possible substitute for soybean meal in diets for these animals. The objective of this study was to evaluate ingestive feeding behavior and physiological parameters of Saanen and AngloNubian goat breeds in confinement.

\section{Material and Methods}

The study was conducted at the Technological Center for Goat Milk Production of Embrapa Goats and Sheep $\left(3^{\circ} 44^{\prime} 57,42^{\prime \prime}\right.$ South and $40^{\circ} 20^{\prime} 43,50^{\prime \prime}$ West), in the city of Sobral-CE, Brazil, from September 2015 to June 2016.

Twenty-four goats (12 Saanen and 12 AngloNubian) with a body weight of $16.22 \pm 0.67 \mathrm{~kg}$ were submitted to a confinement regime in individual, suspended stalls with a $5.06 \mathrm{~m}^{2}$ slab floor, a $2.87 \mathrm{~m}^{2}$ shaded area, equipped with drinkers, feeders, and salt licks. All procedures involving animals were carried out in accordance with the Ethics Committee on Animal Use regulations by the Brazilian Agricultural Research Corporation, National Goat Research Center, protocol number 005/2015.
The treatments consisted of three diets: the first was formulated with corn and soybean meal (SM) and the other two were formulated with castor cake detoxified using either calcium hydroxide $\left(\mathrm{Ca}(\mathrm{OH})_{2}\right.$ DCC) or sodium hydroxide ( $\mathrm{NaOH}$ DCC), with both completely replacing soybean meal. Tifton 85 hay was used as forage. A completely randomized design with $3 \times 2$ (diets $\times$ breeds) factorial arrangement was used with four replicates per combination. In the pre-experimental conditions, goats were identified, treated against ecto- and endoparasites, and administered rabies vaccine.

The experimental diets were formulated based on the recommendations of the National Research Council-NRC (2007); the diets were isoproteic and isoenergetic with a forage: concentrate ratio of 43:57, 40:60, and 36:64 for the $\mathrm{SM}, \mathrm{Ca}(\mathrm{OH})_{2} \mathrm{DCC}$, and $\mathrm{NaOH}$ DCC diets, respectively. The chemical composition of the ingredients is shown in Table 1 , and the proportion of the ingredients of the diets and their chemical composition based on the forage: concentrate ratio are shown in Table 2.

Two alkaline products, $\mathrm{Ca}(\mathrm{OH})_{2}$ and $\mathrm{NaOH}$ in the proportions of 90 and $60 \mathrm{~g} \mathrm{~kg}^{-1}$ of cake, respectively, were used to detoxify the crude castor cake, while $2000 \mathrm{ml}$ of water $\mathrm{kg}^{-1}$ of crude castor cake was used for the dilution and efficacy of the reagents. The cake was detoxified by adapting a semiautomatic mixer for homogenization of the detoxifying solution. A stationary cement mixer equipped with three-phase motor was used (Fischer ${ }^{\circledR}$ MOB 400 G2) to mix the solution. 
Table 1. Chemical composition of the ingredients used for the preparation of the experimental diets.

\begin{tabular}{lccccc}
\hline \multirow{2}{*}{ Item $\left(\mathrm{g} \mathrm{kg} \mathrm{DM}^{-1}\right)$} & \multicolumn{5}{c}{ Ingredients } \\
\cline { 2 - 6 } & Tifton 85 hay & Ground corn & Soybean meal & $\mathrm{Ca}(\mathrm{OH})_{2} \mathrm{DCC}$ & $\mathrm{NaOH} \mathrm{DCC}$ \\
\hline Dry matter $\left(\mathrm{g} \mathrm{kg}^{-1}\right.$ fresh matter $)$ & 872.52 & 889.24 & 870.21 & 904.22 & 904.82 \\
Organic matter & 911.34 & 965.92 & 956.90 & 867.77 & 855.63 \\
Mineral matter & 88.75 & 34.11 & 43.10 & 132.32 & 144.42 \\
Crude protein & 104.12 & 79.50 & 443.30 & 315.41 & 309.01 \\
Ether extract & 14.52 & 36.83 & 28.84 & 52.10 & 47.53 \\
Non-fiber carbohydrates & 277.80 & 722.41 & 320.81 & 103.95 & 132.44 \\
Neutral detergent fiber & 514.90 & 123.28 & 163.84 & 396.18 & 360.12 \\
Acid detergent fiber & 472.22 & 69.07 & 117.93 & 379.22 & 388.74 \\
Hemicellulose & 248.44 & 115.53 & 99.82 & 104.13 & 54.70 \\
Cellulose & 413.65 & 60.22 & 105.60 & 328.50 & 342.63 \\
Lignin & 60.62 & 8.80 & 12.21 & 50.73 & 46.15 \\
Total digestible nutrients & 546.83 & 848.75 & 822.52 & 620.54 & 627.93 \\
\hline
\end{tabular}

${ }^{\mathrm{a}} \mathrm{Ca}(\mathrm{OH})_{2}$ DCC: $0.90 \mathrm{~g} \mathrm{Na} \mathrm{kg}^{-1} \mathrm{DM}$ and $2.25 \mathrm{~g} \mathrm{Ca} \mathrm{kg}^{-1} \mathrm{DM}$; NaOH DCC: $29.20 \mathrm{~g} \mathrm{Na} \mathrm{kg}^{-1} \mathrm{DM}$ and $0.63 \mathrm{~g} \mathrm{Ca} \mathrm{kg}^{-1} \mathrm{DM}^{\mathrm{b}} \mathrm{Corrected}$ for ash and protein.

Table 2. Proportion of ingredients and chemical composition of the experimental diets.

\begin{tabular}{lccc}
\hline \multirow{2}{*}{ Ingredients } & \multicolumn{3}{c}{ Diets } \\
\cline { 2 - 4 } & Soybean meal & DCC Ca(OH) & DCC NaOH \\
\hline Item $\left(\mathrm{g} \mathrm{kg} \mathrm{DM}^{-1}\right)$ & \multicolumn{3}{c}{ Proportion of ingredients } \\
\hline Tifton 85 hay & 427.31 & 394.97 & 363.29 \\
Ground corn & 460.83 & 481.95 & 504.65 \\
Soybean meal & 57.80 & ------- & ------ \\
Detoxified castor cake & ------- & 83.31 & 82.95 \\
Soy oil & 45.03 & 39.94 & 39.25 \\
Limestone & 9.16 & 0.01 & 10.10 \\
Mineral Premix & Ad libitum & Adibitum & Ad libitum \\
Chemical Composition $\left(\mathrm{g} \mathrm{kg}^{-1} \mathrm{DM}\right)$ & & & \\
Dry matter $\left(\mathrm{g} \mathrm{kg}^{-1}\right.$ fresh matter) & 887.71 & 896.13 & 891.84 \\
Organic matter & 942.37 & 897.85 & 938.10 \\
Mineral matter & 57.74 & 102.26 & 61.98 \\
Crude protein & 112.01 & 112.91 & 112.32 \\
Ether extract & 62.02 & 63.40 & 65.43 \\
Non-fiber carbohydrates & 471.86 & 468.64 & 476.80 \\
Neutral detergent fiber & 287.94 & 297.63 & 279.24 \\
Acid detergent fiber & 349.52 & 332.05 & 305.44 \\
Hemicellulose & 166.01 & 163.65 & 152.67 \\
Cellulose & 211.82 & 221.11 & 209.33 \\
Lignin & 30.86 & 32.68 & 30.32 \\
Total digestible nutrients & 664.98 & 658.58 & 663.61 \\
\hline
\end{tabular}

${ }^{\mathrm{a}}$ Guaranteed levels (per kg, in active elements): calcium $-218.00 \mathrm{~g}$; phosphorus $-71.00 \mathrm{~g}$; sulfur $-20.00 \mathrm{~g}$; iron $-1800.00 \mathrm{mg}$; iodine $-80.00 \mathrm{mg}$; manganese $-1300.00 \mathrm{mg}$; selenium $-15.00 \mathrm{mg}$; zinc $-3800.00 \mathrm{mg}$; molybdenum $-300.00 \mathrm{mg}$; maximum fluorine $-870.00 \mathrm{mg}$; phosphorus (P) solubility in citric acid $2 \%$ minimum - $95 \%$.

${ }^{\mathrm{b}}$ Corrected for ash and protein. 
A vertical electrophoresis apparatus was used (model 2001, Amsterdam - Pharmacia, Uppsala, Sweden) to analyze the electrophoretic profile of the proteins from the castor bean cake and identify the ricin. SDS-PAGE was performed according to the methodology described by Laemmli and Favre (1973). Densitometry of the gels was performed using the Gel Analizer ${ }^{\circledR}$ application in order to confirm the disappearance of the bands, as shown in Figure 1.

On the day of the behavior assay, the feed was delivered at $08 \mathrm{~h} 00$ and at $16 \mathrm{~h} 00$ in sufficient quantity to allow a $10 \%$ of the supply as leftovers. Samples were taken from the supplied diet (both the forage and the concentrate), as well as from the leftovers the following day, which were then packed into plastic bags, properly identified, and stored in a freezer at $-8{ }^{\circ} \mathrm{C}$. Dry matter (DM; method number 934.01), organic matter (method number 942.05), crude protein (method number 954.01), and ethereal extract levels (method number 920.39) were subsequently determined from the samples (leftovers and supplied) according to AOAC (2003). For neutral detergent fiber (NDF) analyses, the samples were treated with thermostable alphaamylase, without the use of sodium sulfite and corrected for residual ash (MERTENS, 2002).

To formulate the diets, the content of nitrogen compounds insoluble in neutral (NIDN) and acid detergents (NIDA) was estimated according to Licitra et al. (1996). Lignin content was obtained using the methodology described in Detmann et al. (2012), with FDA residue treated with $72 \%$ sulfuric acid. Non-fibrous carbohydrate (NFC) content was calculated by an adaptation of the method proposed by Hall (2003). Total carbohydrate (TC) content was obtained by the equation proposed by Sniffen et al. (1992). Total digestible nutrients (NDT) were calculated according to Weiss (1999).

Figure 1. Electrophoretic characterization of castor cake proteins treated with different chemical products. 1: Molecular weight marker (kDa); L: Lectins; 2: Crude castor cake; 3: Detoxified castor cake $\mathrm{Ca}(\mathrm{OH})_{2}$; 4: Detoxified castor cake $\mathrm{NaOH}$.

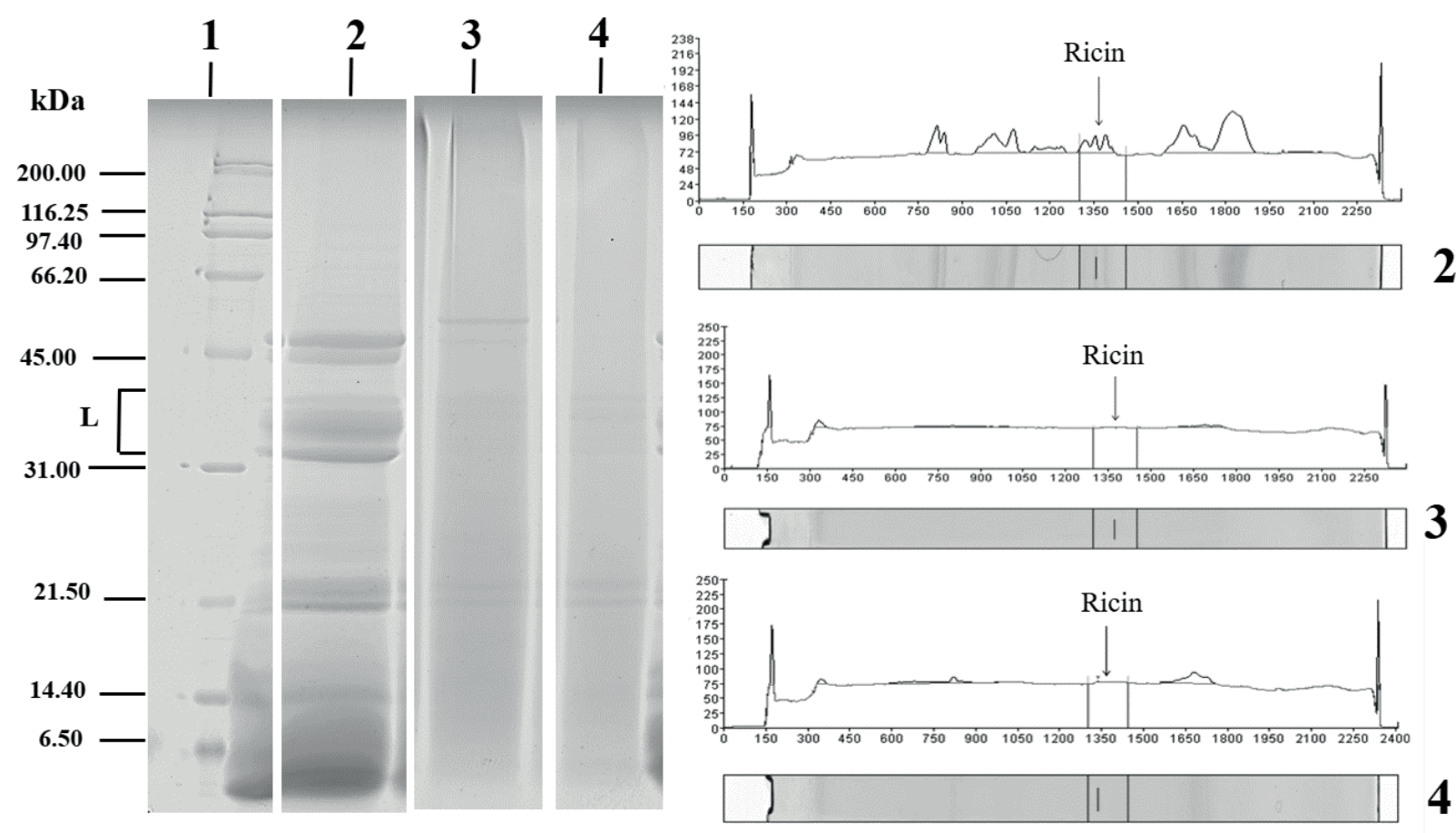


Feeding behavior observations were performed instantaneously at 10-minute intervals (feed intake, rumination, other activities, and idle) for 24 hours. Moreover, the frequency of water intake, urination and defecation were monitored in the interval between two observations. On the following day, collections were made during three two-hour periods (between $08 \mathrm{~h} 00$ and $10 \mathrm{~h} 00 ; 14 \mathrm{~h} 00$ and 16h00; and $18 \mathrm{~h} 00$ and 20h00), to estimate the number of rumination chews per bolus (RCnb) and time elapsed with rumination chews per bolus (RCtb) using a digital timer. The methodology reported by Bürger et al. (2000) was used to determine feed efficiency (FE) and rumination efficiency (RE) as a function of DM $\left(\mathrm{g} \mathrm{DM} \mathrm{h}^{-1}\right)$ and NDF.

The physiological parameters of respiratory rate (RR), heart rate (HR), rectal temperature (RT), and body surface temperature (BST) were measured during three consecutive days at the following times: from $07 \mathrm{~h} 00$ to $08 \mathrm{~h} 00,12$ to $13 \mathrm{~h} 00$, and $18 \mathrm{~h} 00$ to 19h00. RT was determined by introducing a digital clinical thermometer (Techline ${ }^{\circledR}$ TS-101PM; range, up to $42.9^{\circ} \mathrm{C}$ ) directly into the animal's rectum.

BST corresponded to the average temperatures obtained from five determined regions of the body: forehead (FST), neck (NST), rump (RST), back (BST), and womb (WST) surface temperatures using a non-contact digital infrared thermometer (ICEL-Manaus ${ }^{\mathbb{B}}$ - TD-950). RR and HR were obtained using a flexible stethoscope. Measurements were made at the laryngo-tracheal region for RR, counting the number of movements in 15 seconds; the value obtained was multiplied by four, with values expressed as movements minute ${ }^{-1}$. Measurements were made for one minute between the third and fourth intercostal space close to the costochondral joint for HR, with values expressed as beats minute ${ }^{-1}$.

Data were initially subjected to normality tests (Shapiro-Wilk) and homoscedasticity tests (Levene), and were also submitted to analysis of variance by the $\mathrm{F}$ test when the presuppositions were met, by using the following model:

$$
\mathrm{Y}_{\mathrm{ijk}}=\mu+\alpha_{\mathrm{i}}+\beta_{\mathrm{j}}+(\propto \beta)_{\mathrm{ij}}+\mathrm{e}_{\mathrm{ijk}} \text {, }
$$

where $\mathrm{Y}_{\mathrm{ijk}}$ is the dependent variable corresponding to the experimental observation; $\mu$ is the overall mean; $\alpha i$ is the fixed effect of the diets; $\beta$ is the fixed effect of the breed; $(\alpha \beta)_{\mathrm{ij}}$ is the interaction effect; and $\mathrm{e}_{\mathrm{ijk}}$ is the random error, assuming an independent normal distribution. Interaction between breed and diet was only considered when significant at 5\% probability. A comparison of means was carried out by Tukey test at $5 \%$ probability to evaluate the effects of breed and diet. Statistical analyses were performed using the GLM procedure of the SAS software version 9.3 (SAS INSTITUTE, 2005).

\section{Results and Discussion}

Diets affected DM and NDFap intakes $(\mathrm{P}=0.02$ and 0.01$)$; however, no effect was noted for breed $(\mathrm{P}>0.05)$. DM and NDFap intakes were higher for goats fed $\mathrm{SM}$ and $\mathrm{Ca}(\mathrm{OH})_{2}$ DCC (Table 3 ). The diets influenced ( $\mathrm{P}=0.03)$ rumination and feeding time, with high feeding and rumination times for goats fed $\mathrm{SM}$ and $\mathrm{Ca}(\mathrm{OH})_{2}$ DCC diets; no difference was noted between these diets. An interaction between breed and diet was observed ( $\mathrm{P}=0.04$ and 0.01 ) for time variables (other activities and idle time). The same trend was observed when the animals were idle.

The low intake of DM and NDFap by goats fed $\mathrm{NaOH}$ DCC might be related to the sodium content in the detoxified DCC (Table 1). The amount of sodium in $\mathrm{NaOH}$ DCC (Table 1) was 32.40 times higher than that in $\mathrm{Ca}(\mathrm{OH})_{2}$ DCC. According to Paulino et al. (2001), the inclusion of increased amounts of sodium in the diet of ruminants causes a self-regulating voluntary intake effect in the animals.

The rumination time in this study was close to the 403 minutes day $^{-1}$ of rumination observed by Vieira et al. (2011) when SM was completely replaced with castor bean meal in sheep diet. The 
low rumination and feeding times that we observed are directly related to the low DM intake, since according to Queiroz et al. (2001), the time spent ruminating depends on the diet type and seems to show little variation among grain-rich diets, reaching a maximum of 600 minutes day ${ }^{-1}$ when fed diets rich in forage. Moreover, the food intake level also influences rumination time because a greater amount of food needs to be fragmented before being digested. Additionally, the low forage: concentrate ratio in the $\mathrm{NaOH}$ DCC diet (36:64) may have contributed to the short rumination time, as according to Giger-Reverdin et al. (2014), small concentrate particle sizes allow for high rates of food passage.
From another perspective, rumination time is directly related to NDFap intake, since according to Van Soest (1994), increased fiber intake promotes an increase in rumination time due to the greater need of processing fiber. Oliveira et al. (2016) evaluated the inclusion of castor bean meal detoxified using calcium oxide on the feeding behavior of lambs and found that the rumination time was above 500 minutes day $^{-1}$; they also showed a proportional increase in rumination time with the amount of bran in the diet. However, in their study, the NDFap content of the diets was above $47 \%$, whereas in this study, the NDFap content of the diets was below $30 \%$, which may have contributed to the low rumination time.

Table 3. Dry matter intake (DM), Neutral detergent fiber corrected for ash and protein $\left(\mathrm{NDF}_{\mathrm{ap}}\right)$ and behavior al activities of goats fed detoxified castor cake.

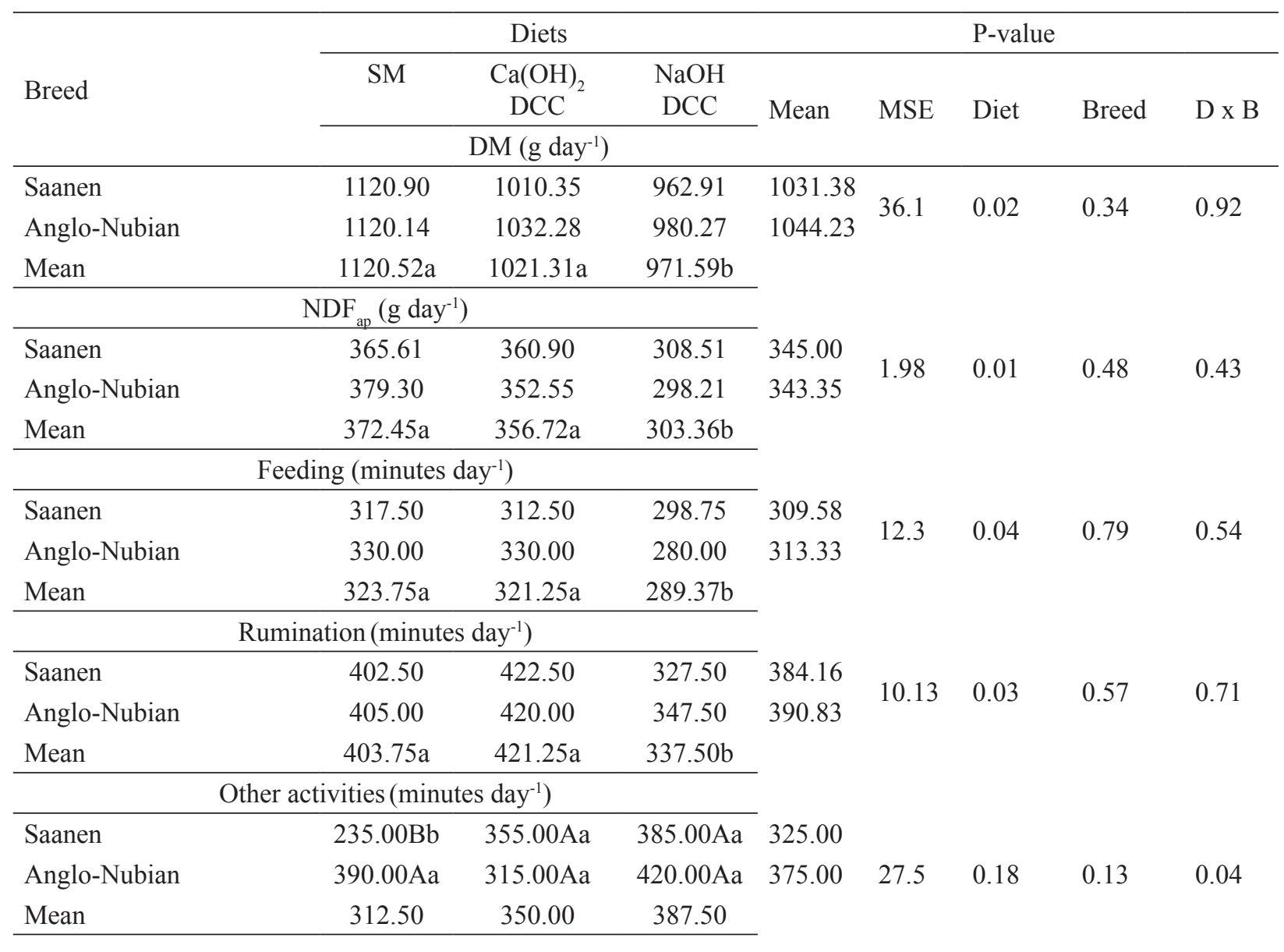


continuation

\begin{tabular}{|c|c|c|c|c|c|c|c|c|}
\hline \multicolumn{4}{|c|}{ Idle (minutes day ${ }^{-1}$ ) } & & \multirow{3}{*}{28.77} & \multirow{3}{*}{0.17} & \multirow{3}{*}{0.08} & \multirow{3}{*}{0.01} \\
\hline Saanen & $485.00 \mathrm{Aa}$ & $320.00 \mathrm{Ab}$ & $458.75 \mathrm{Aa}$ & 360.83 & & & & \\
\hline Anglo-Nubian & $315.00 \mathrm{Ba}$ & $375.00 \mathrm{Aa}$ & $392.50 \mathrm{Aa}$ & 421.25 & & & & \\
\hline Mean & 400.00 & 347.50 & 425.62 & & & & & \\
\hline
\end{tabular}

MSE: Mean standard error

Averages followed by common lowercase letters in the lines and by uppercase letters in the columns do not differ from one another according to the Tukey test at $5 \%$ significance.

Throughout the experiment, Anglo-Nubian goats showed less adaptation to the confined environment, as they are less docile than are Saanen goats. Because the activities involved in feeding behavior are considered exclusive, long feeding times for goats fed SM reflected short times dedicated to other activities (idle and other activities). The increase in idle time is of fundamental importance for production animals, since idle animals show reduced energy expenditure (MISSIO et al., 2010). However, the DM intake should meet their nutritional requirements.

Gomes et al. (2017) evaluated the behavior in sheep fed diets containing castor oil cake (crude or detoxified using different alkaline products) and found that only diets with detoxified urea cake reduced the idle time of the animals. Palmieri et al. (2017) evaluated the effect of including detoxified castor bean meal in diets of growing goats and found no changes in feeding, rumination, or idle times; however, they found a reduction in DM intake and in RE of DM.

Low FE of NDF was observed for goats fed $\mathrm{NaOH}$ DCC diets, while the lowest NDF RE was found for goats fed SM, which did not differ from those in goats fed $\mathrm{Ca}(\mathrm{OH})_{2}$ DCC (Table 4).

Table 4. Dry matter feed efficiency $\left(\mathrm{FE}_{\mathrm{DM}}\right)$, neutral detergent fiber feed efficiency $\left(\mathrm{FE}_{\mathrm{NDF}}\right)$, rumination efficiency of dry matter $\left(\mathrm{RE}_{\mathrm{DM}}\right)$, rumination efficiency of neutral detergent fiber $\left(\mathrm{RE}_{\mathrm{NDF}}\right)$, total chewing time (TCT) and number of ruminal bolus (NRB) of goats fed detoxified castor cake.

\begin{tabular}{|c|c|c|c|c|c|c|c|c|}
\hline \multirow{3}{*}{ Breed } & \multicolumn{3}{|c|}{ Diets } & & \multirow{3}{*}{ MSE } & \multicolumn{3}{|c|}{ P-value } \\
\hline & \multirow[t]{2}{*}{ SM } & $\begin{array}{c}\mathrm{Ca}(\mathrm{OH})_{2} \\
\mathrm{DCC}\end{array}$ & $\begin{array}{c}\mathrm{NaOH} \\
\mathrm{DCC}\end{array}$ & \multirow[b]{2}{*}{ Mean } & & \multirow[t]{2}{*}{ Diet } & \multirow[t]{2}{*}{ Breed } & \multirow[t]{2}{*}{$\mathrm{D} \times \mathrm{B}$} \\
\hline & & ${ }_{\mathrm{DM}}(\mathrm{g}$ DM & & & & & & \\
\hline Saanen & 190.00 & 199.84 & 190.00 & 199.84 & \multirow{3}{*}{12.67} & \multirow{3}{*}{0.95} & \multirow{2}{*}{0.87} & \multirow{2}{*}{0.71} \\
\hline Anglo-Nubian & 206.66 & 186.70 & 206.66 & 186.70 & & & & \\
\hline Mean & $198.33 a$ & $193.27 \mathrm{a}$ & $198.33 \mathrm{a}$ & & & & & \\
\hline \multicolumn{5}{|c|}{$\mathrm{FE}_{\mathrm{NDF}}\left(\mathrm{g} \mathrm{NDF} \mathrm{h}^{-1}\right)$} & \multirow{4}{*}{4.69} & \multirow{4}{*}{0.03} & \multirow{4}{*}{0.93} & \multirow{4}{*}{0.72} \\
\hline Saanen & 73.83 & 70.13 & 54.27 & 66.07 & & & & \\
\hline Anglo-Nubian & 79.24 & 64.86 & 55.41 & 66.50 & & & & \\
\hline Mean & $76.54 a$ & $67.50 \mathrm{ab}$ & $54.84 \mathrm{~b}$ & & & & & \\
\hline \multicolumn{5}{|c|}{$\mathrm{RE}_{\mathrm{DM}}\left(\mathrm{g} \mathrm{DM} \mathrm{h}^{-1}\right)$} & \multirow{4}{*}{9.41} & \multirow{4}{*}{0.53} & \multirow{4}{*}{0.69} & \multirow{4}{*}{0.88} \\
\hline Saanen & 154.07 & 153.95 & 161.32 & 156.45 & & & & \\
\hline Anglo-Nubian & 153.61 & 155.55 & 173.39 & 160.85 & & & & \\
\hline Mean & $153.84 \mathrm{a}$ & $154.75 \mathrm{a}$ & $167.36 \mathrm{a}$ & & & & & \\
\hline
\end{tabular}


continuation

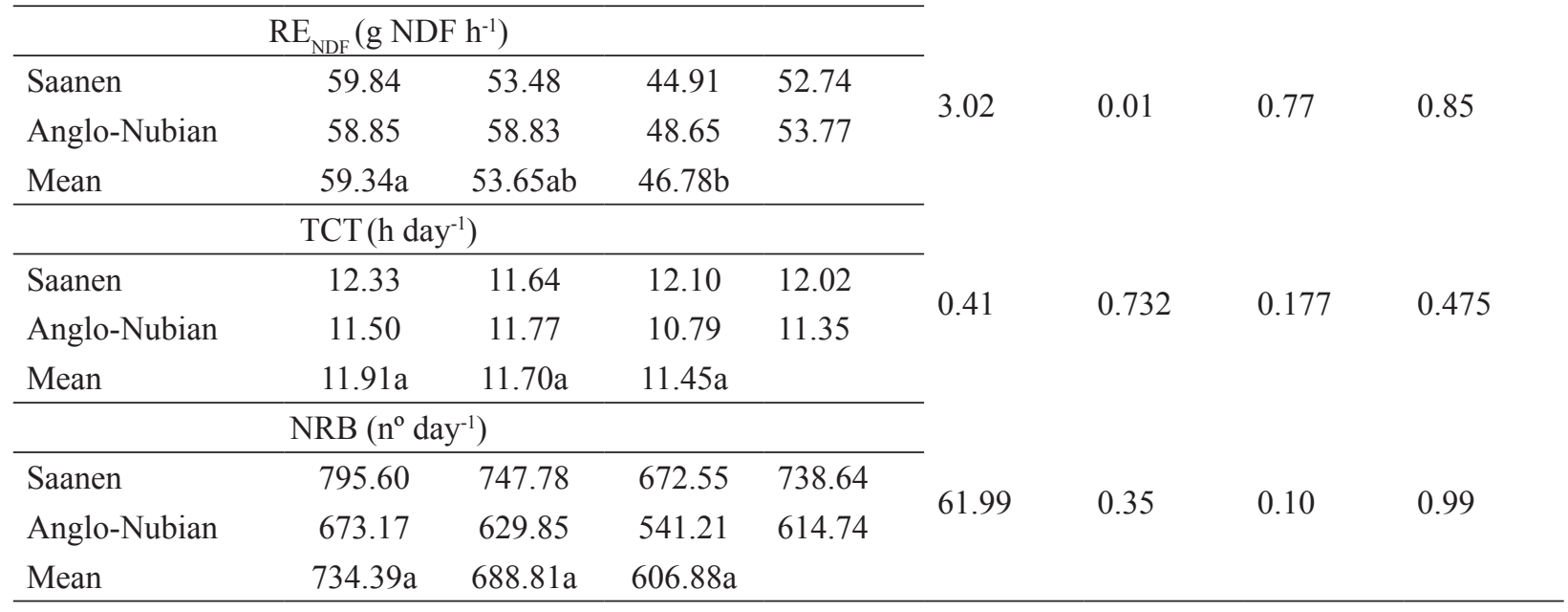

MSE: Mean standard error

Averages followed by common lowercase letters in the lines and by uppercase letters in the columns do not differ from one another according to the Tukey test at $5 \%$ significance.

The different diets had an effect $(\mathrm{P}=0.03)$ on the frequency of water intake and interaction $(\mathrm{P}=$ 0.02 ), and on the frequency of daily urination (Table
5). We found that Anglo-Nubian goats fed SM diet urinated less than Saanen goats fed the same diet.

Table 5. Water intake (WI), Urination (URI) and defecation (DEF) of goats fed detoxified castor cake.

\begin{tabular}{|c|c|c|c|c|c|c|c|c|}
\hline \multirow{3}{*}{ Breed } & \multicolumn{3}{|c|}{ Diets } & & \multirow{3}{*}{ MSE } & \multicolumn{3}{|c|}{ P-value } \\
\hline & SM & $\begin{array}{c}\mathrm{Ca}(\mathrm{OH})_{2} \\
\mathrm{DCC}\end{array}$ & \multirow{2}{*}{$\begin{array}{l}\mathrm{NaOH} \\
\mathrm{DCC} \\
\left.\mathrm{ay}^{-1}\right)\end{array}$} & \multirow[b]{2}{*}{ Mean } & & \multirow[t]{2}{*}{ Diet } & \multirow[t]{2}{*}{ Breed } & \multirow[t]{2}{*}{$\mathrm{D} \times \mathrm{B}$} \\
\hline & \multicolumn{2}{|c|}{ Water intake (times day $\left.{ }^{-1}\right)$} & & & & & & \\
\hline Saanen & 3.25 & 4.25 & 5.25 & $4.25 \mathrm{~A}$ & \multirow{3}{*}{0.69} & \multirow{3}{*}{0.03} & \multirow{2}{*}{0.26} & \multirow{2}{*}{0.18} \\
\hline Anglo-Nubian & 2.75 & 1.25 & 6.00 & $3.33 \mathrm{~A}$ & & & & \\
\hline Mean & $3.00 \mathrm{~b}$ & $2.75 \mathrm{~b}$ & $5.62 \mathrm{a}$ & & & & & \\
\hline \multicolumn{4}{|c|}{ Urination (times day ${ }^{-1}$ ) } & & \multirow{4}{*}{0.77} & \multirow{4}{*}{0.47} & \multirow{4}{*}{0.27} & \multirow{4}{*}{0.02} \\
\hline Saanen & $6.75 \mathrm{Aa}$ & $5.50 \mathrm{Aa}$ & $7.75 \mathrm{Ba}$ & 6.66 & & & & \\
\hline Anglo-Nubian & $5.50 \mathrm{Aa}$ & $4.25 \mathrm{Aa}$ & $2.25 \mathrm{Ab}$ & 4.00 & & & & \\
\hline Mean & 6.12 & 4.87 & 5.00 & & & & & \\
\hline \multicolumn{4}{|c|}{ Defecation (times day-1) } & & \multirow{4}{*}{0.76} & \multirow{4}{*}{0.58} & \multirow{4}{*}{0.64} & \multirow{4}{*}{0.59} \\
\hline Saanen & 4.50 & 4.75 & 4.75 & $4.66 \mathrm{~A}$ & & & & \\
\hline Anglo-Nubian & 5.00 & 4.00 & 6.25 & $5.08 \mathrm{~A}$ & & & & \\
\hline Mean & $4.75 \mathrm{a}$ & $4.37 \mathrm{a}$ & $5.50 \mathrm{a}$ & & & & & \\
\hline
\end{tabular}

MSE: Mean standard error

Averages followed by common lowercase letters in the lines and by uppercase letters in the columns do not differ from one another according to the Tukey test at $5 \%$ significance. 
According to Neiva et al. (2004), the frequency of water intake directly correlates with DM intake. However, in this study, the inverse occurred, as goats fed $\mathrm{NaOH}$ DCC consumed low amounts of DM. This behavior can be explained by two factors. The first is related to the sodium content in $\mathrm{NaOH}$ DCC diets, i.e., the large amount of sodium in this diet (Table 1) reduced DM intake (Table 3). Large amounts of sodium in the diet alter the tonicity of the ruminal environment, creating an imbalance in the sodium level in the rumen compared to the other organs in the animal's body, leading to an increase in the frequency of water intake in order to dilute the sodium and render the medium isotonic (KOZLOSKI, 2011; MCKINLEY; JOHNSON, 2004).

The second factor is related to NDF intake and is a consequence of the former. Goats fed SM and $\mathrm{Ca}(\mathrm{OH})_{2}$ DCC diets consumed large amounts of NDF, resulting in long rumination time (Table 3 ). This behavior stimulated increased saliva flow, thereby increasing DM dilution rate in the rumen. In contrast, goats fed $\mathrm{NaOH}$ DCC consumed low amounts of NDF, thereby low rumination times, which resulted in a low dilution rate, requiring high water intake frequency.

A factor that may have influenced the low urinary frequency in Anglo-Nubian animals is the dark fur coloration of these goats, which promotes increased absorption of heat from the environment, leading to increased thermal stress. In such animals, heat dissipation occurs through the conversion of water into vapor, by both sweat secreted by the skin glands and moisture of the respiratory tract (MORANDFEHR; DUREAU, 2001), justifying the low urinary frequency.

Dietary effects on HR and RT $(\mathrm{P}=0.01$ and 0.02$)$ were observed, whereas BST was influenced by the breed of the animals. The high RH for animals fed the SM diet should be related to the high DM intake and rumination time of the animals, since according to Kolb and Gürtler (1987), the ingestion of large amounts of food causes a considerable increase in $\mathrm{HR}$, and rumination changes the HR by $3 \%$. The animals fed this diet consumed large amounts of DM and presented high rumination times (Table 6). Despite the observed variation, all the animals presented HRs within the normal range, 70-90 beats per $\min ^{-1}$ (KELLY, 1976).

The high feed intake and long rumination time (Table 3), along with the low frequency of water intake, probably increased the internal temperature of the goats fed $\mathrm{SM}$ and $\mathrm{Ca}(\mathrm{OH})_{2}$ DCC diets, while goats fed $\mathrm{NaOH}$ DCC diet had low caloric increase because of low feed intake and high water intake, thus, dissipating metabolic heat. RT is a good indicator of the dietary effect on the energy produced by metabolism: an increase in the RT means that the animal is retaining heat, and if this heat is not dissipated, caloric stress can occur (CUNNINGHAM, 2014). Despite the minor observed variations, the goats in our study did not show stress from the diets, considering that according to Kelly (1976), the physiological reference for $\mathrm{RT}$ in goats at rest is $38.50{ }^{\circ} \mathrm{C}$ to 39.70 ${ }^{\circ} \mathrm{C}$.

The BST of Anglo-Nubian goats was higher than that of Saanen goats, which is related to the color of their coats. Similar to the trend observed for the urinary frequency, the light coat color of Saanen goats reflects more heat, which, despite their stalls being covered/shaded, promotes greater reflection of heat from the environment. This is in contrast to the Anglo-Nubian goats, which in turn absorb greater amounts of heat due to their darker and spotted fur/coat. Silva et al. (2006) reported lower surface temperatures in Savana goats than in Anglo-Nubian, confirming that the light coat color of Savana goats facilitates heat reflection. 
Table 6. Heart rate (HR), respiratory rate (RR), rectal temperature (RT) and body surface temperature (BST) of goats fed detoxified castor cake.

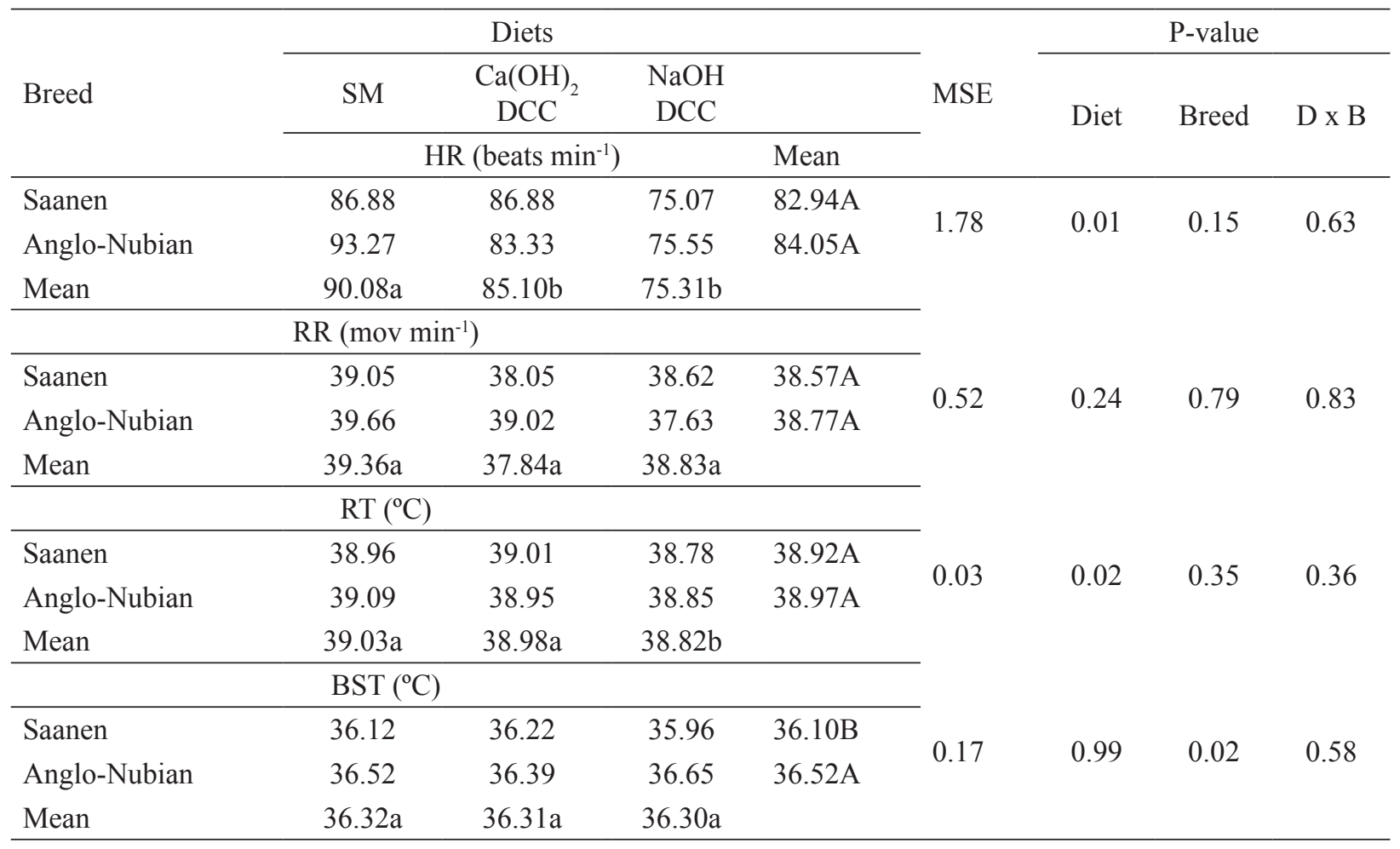

MSE: Mean standard error

Averages followed by common lowercase letters in the lines and by uppercase letters in the columns do not differ from one another according to the Tukey test at $5 \%$ significance.

\section{Conclusions}

Castor cake detoxified using sodium hydroxide reduces the dry matter intake and feed efficiency of dairy goats. Physiological parameters are influenced by both diets and breed, without any negative changes that indicate animal stress or discomfort.

\section{Acknowledgements}

The authors are grateful to the Coordenação de aperfeiçoamento de Pessoal do Nível Superior (CAPES) for financing the Project and for Postgraduate scholarships; to Embrapa Caprinos e Ovinos for all the technical and installation/ infrastructure support; to the Conselho Nacional de Pesquisa (CNPQ) for the grants; to Agroindústria OLVEq Ltda. for donating the castor cake for conducting the research and the technique of the Laboratory of Embrapa Lidiane Viana Ximenes by chromatographic analyzes

\section{References}

ASLANI, M. R.; MALEKI, M.; MOHRI, M.; SHARIFI, K.; NAJJAR-NEZHAD, V.; AFSHARI, E. Castor Bean (Ricinus communis) toxicosis in a sheep flock. Toxicon, Iowa City, v. 49, n. 3, p. 400-406, 2007.

ASSOCIATION OF ANALYTICAL CHEMISTS AOAC. Official methods of analysis. 17. ed. Gaithersburg, M.D. 2003. 1094 p.

BÜRGER, P. J.; PEREIRA, J. C.; QUEIROZ, A. C.; SILVA, J. F. C.; VALADARES FILHO, S. C.; CECON, P. R.; CASALI, A. D. P. Ingestive behaviour in holstein calves fed diets with different concentrate levels. Revista Brasileira de Zootecnia, Viçosa, v. 29, n. 1, p. 236-242, 2000. 
CUNNINGHAM, J. G.; KLEIN, B. G. Tratado de fisiologia veterinária. 5. ed. Rio de Janeiro: Elsevier, 2014. 624 p.

DETMANN, E.; SOUZA, M. A.; VALADARES FILHO, S. C.; QUEIROZ, A. C.; BERCHIELLI, T. T.; SALIBA, E. O. S.; CABRAL, L. S.; PINA, D. S.; LADEIRA, M. M.; AZEVEDO, J. A. G. Métodos para análise de alimentos. INCT - Ciência Animal. Visconde do Rio Branco: Suprema, 2012. 214 p.

FURTADO, R. N.; CARNEIRO, M. S. S.; CANDIDO, M. J. D.; GOMES, F. H. T.; PEREIRA, E. S. Valor nutritivo de dietas contendo torta de mamona submetida a métodos alternativos de destoxificação para ovinos. Arquivo Brasileiro de Medicina Veterinária e Zootecnia, Belo Horizonte, v. 64, n. 1, p. 155-162, 2012.

GIGER-REVERDIN, S.; RIGALMA, K., DESNOYERS, M.; SAUVANT, D.; DUVAUX-PONTER, C. Effect of concentrate level on feeding behaviour and rumen and blood parameters in dairy goats: Relationships between behavioural and physiological parameters and effect of between-animal variability. Journal of Dairy Science, IIlinois, v. 97, n. 1, p. 4367-4378, 2014.

GIONBELLI, T. R. S.; VELOSO, C. M.; GIONBELLI, M. P.; NOVAIS, M. A. S.; SILVA, A. L.; ESPECHIT, C. J. B.; CAMPOS, J. M. S.; VALADARES FILHO, S. C.; PEREIRA, O. G.; CUNHA, C. S.; ALCÂNTARA, P. H.; VIRGÍNIO JUNIOR, G. F.; DUARTE, M. S. Utilization of castor bean meal treated with calcium hydroxide fed wet or dry by lambs. Livestock Science, Amsterdam, v. 168, n. 1, p. 76-783, 2014.

GOMES, F. H. T.; CANDIDO, M. J. D.; CARNEIRO, M. S. S.; FURTADO, R. N. F.; PEREIRA, E. S. Intake, behaviour and performance in sheep fed diets containing castor cake. Revista Ciência Agronômica, Fortaleza, v. 48, n. 1, p. 182-190, 2017.

HALL, M. B. Challenges with non-fiber carbohydrate methods. Journal of Animal Science, Champaigne, v. 81, n. 1, p. 3226-3232, 2003.

KELLY, W. R. Veterinary clinical diagnosis. 2. ed. Barcelona: Continental, 1976. 444 p.

KOLB, E., KETZ, A. E GÜRTLER, H. Veterinary physiology. 4. ed. Rio de Janeiro: Guanabara Koogan, 1987. $612 \mathrm{p}$.

KOZLOSKI, G. V. Biochemistry of ruminants. 3. ed. Santa Maria: UFSM, 2011. 280 p.

LAEMMLI, U. K.; FAVRE, M. Maturation of the head of bacteriophage T4. I. DNA packaging events. Journal of Molecular Biology, San Diego, v. 80, n. 4, 575-599, 1973.
LICITRA, G.; HERNANDEZ, T. M.; VAN SOEST, P. J. Standardization of procedures for nitrogen fractionation of ruminant feeds. Animal Feed Science and Technology, Missouri, v. 57, n. 1, p. 347-358, 1996.

MCKINLEY, M. J.; JOHNSON, A. K. The physiological regulation of thirst and fluid intake. News in Physiological Sciences, Minnesota, v. 19, n. 1, p. 1-6, 2004.

MERTENS, D. R. Gravimetric determination of amylasetreated neutral detergent fiber in feeds with refluxing in beakers or crucibles: collaborative study. Journal of AOAC International, Gaithersburg, v. 85, n. 6, p. 12171240. 2002.

MISSIO, R. L.; BRONDANI, I. L.; ALVES FILHO, D. C.; SILVEIRA, M. F.; FREITAS, L. S.; ESTLE, J. Ingestive behaviour of feedlot finished young bulls fed different concentrate levels in the diet. Revista Brasileira de Zootecnia, Viçosa, v. 39, n. 7, p. 1571-1578, 2010.

MORAND-FEHR, P.; DOREAU, M. Ingestion et digestion chez les ruminants soumis à un stress de chaleur. INRA Productions Animales, Paris, v. 14, n. 1, p. 15-27, 2001.

NEIVA, J. N. M.; TEIXEIRA, M.; TURCO, S. H. T.; OLIVEIRA, S. M. P.; MOURA, A. A. A. N. Effects of environmental stress on physiological parameters of feedlot sheep in the Northeast of Brazil. Revista Brasileira de Zootecnia, Viçosa, v. 33, n. 3, p. 668-678, 2004.

NICORY, I. M. C.; CARVALHO, G. G. P.; RIBEIRO, O. L.; SANTOS, S. A.; SILVA, F. F.; SILVA, R. R.; LOPES, L. S. C.; SOUZA, F. N. C.; FREITAS JUNIOR, J. E. Productive and metabolic parameters in lambs fed diets with castor seed meal. Livestock Science, Amsterdam, v. 181, n. 2, p. 171-178, 2015.

NATIONAL RESEARCH COUNCIL - NRC. Nutrient requirements of small ruminants. Washington, DC. 2007. p. 384.

OLIVEIRA, F. M.; OLIVEIRA, G. J. C.; OLIVEIRA, M. L. A.; JAEGER, S. M. P. L.; ALMEIDA, L. H. S.; NERY, I. B. Q.; LEITE, L. C. Intake and digestibility of nutrients in sheep fed fodder salt of faveleira (Cnidoscolus phyllacanthus). Revista Brasileira de Saúde e Produção Animal, Salvador, v. 17, n. 3, p. 497-507, 2016.

PALMIERI, A. D.; CARVALHO, G. G. P.; TOSTO, M. S.; LEITE, V. M. L.; SANTOS, S. A.; BORJA, M. S.; AZEVÊDO, J. A. G.; FREITAS JÚNIOR, J. E.; LEITE, L. C.; RUFINO, L. M. A. Feeding behaviour of finishing goats fed diets containing detoxified castor meal, coproduct of the biodiesel industry. Tropical Animal Health and Production, Amsterdam, v. 49, n. 6, p. 389-395, 2017. 
PAULINO, M. F.; DETMANN, E.; ZERVOUDAKIS, J. T. Suplementos múltiplos para recria e engorda de bovinos em pastejo. In: SIMPÓSIO DE PRODUÇÃO DE GADO DE CORTE, 2., 2001, Viçosa, MG. Proceeding... Viçosa, MG, 2001. p.187-231.

POMPEU, R. C. F. F.; CANDIDO, M. J. D.; PEREIRA, E. S.; BOMFIM, M. A. D.; CARNEIRO, M. S. S.; ROGÉRIO, M. C. P.; SOMBRA, W. A.; LOPES, M. N. Performance and carcass traits of sheep in feedlot and fed diets containing detoxified castor cake replacing soybean meal. Revista Brasileira de Zootecnia, Viçosa, v. 41, n. 3, p. 726-733, 2012.

QUEIROZ, A. C.; NEVES, J. S.; MIRANDA, L. F.; PEREIRA, E. S.; DUTRA, A. R. Effect of fiber levels and protein sources on the eating behaviour of crossbred Holstein-Zebu heifers. Arquivo Brasileiro de Medicina Veterinária e Zootecnia, Belo Horizonte, v. 53, n. 1, p. 84-88, 2001.

STATISTICAL ANALYSIS SYSTEM - SAS. System for Microsoft Windows. Cary: Statistical Analysis System, 2005. CD-ROM.

SEVERINO, L. S.; AULD, D. L.; BALDANZI, M.; CANDIDO, M. J. D.; CHEN, G.; CROSBY, W.; TAN, D.; HE, X. H.; LAKSHMAMMA, P.; LAVANYA, C.; MACHADO, O. L. T.; MIELKE, T.; MILANI, M.; MILLER, T. D.; MORRIS, J. B.; MORSE, S. A.; NAVAS, A. A.; SOARES, D. J.; SOFIATTI, V.; WANG, M. L.; ZANOTTO, M. D.; ZIELER, H. A Review on the challenges for increased production of castor. Agronomy Journal, Madison, v. 104, n. 1, p. 853-880, 2012.
SILVA, E. M. N.; SOUZA, B. B.; SILVA, G. A. S.; CEZAR, M. F.; SOUZA, W. H.; BENÍCIO, T. M. A.; FREITAS, M. M. S. Evaluation of the adaptability of goats exotic and native of the semi-arid of Paraiba. Ciência e Agrotecnologia, Lavras, v. 30, n. 3, p. 516-521, 2006.

SNIFFEN, C. J.; O’CONNOR, J. D.; VAN SOEST, P. J.; FOX, D. G.; RUSSELL, J. B. A net carbohydrate and protein system for evaluating cattle diets: carbohydrate and protein availability. Journal Animal Science, Savoy, v. 70, n. 11, p. 3562-3577, 1992.

VAN SOEST, P. J. Nutritional ecology of the ruminants. 2. ed. Ithaca: Cornell University Press, 1994. 476 p.

VIEIRA, M. M. M.; CANDIDO, M. J. D.; BOMFIM, M. A. D.; SEVERINO, L. S.; PEREIRA, E. S.; BESERRA, L. T.; MENESES, A. J. G.; FERNANDES, J. P. B. Ingestive behaviour of sheep fed diets containing four levels of castor meal. Revista Ceres, Viçosa, v. 58, n. 2, p. 444-451, 2011.

WEISS, W. Energy prediction equations for ruminant. In: CORNELL NUTRITION CONFERENCE FOR FEED MANUFACTURES, 61., Ithaca, 1999. Proceedings... Ithaca: Cornell University, 1999. p. 176-185.

WORBS, S.; KÖHLER, K.; PAULY, D.; AVONDET, M. A.; SCHAER, M.; DORNER, M. B.; DORNER, B. G. Ricinus communis intoxications in human and veterinary medicine: a summary of real cases. Toxicons, Minneapolis, v. 3, n. 1, p. 1332-1372, 2011. 
